Available online at website :

http:// e-journal.adpgmiindonesia.com/index.php/jmie

JMIE: Journal of Madrasah Ibtidaiyah Education, 5(2), 2021, 249-263

\title{
KOMPETENSI GURU DALAM MENGAJARKAN MULTILITERASI DI SEKOLAH DASAR
}

\author{
Muh Erwinto Imran'), Wahyu Sopandi'2), Bachrudin Musthafa', \\ Cepi Riyana4), Sartono ${ }^{5}$ \\ Universitas Muhammadiyah Makassar ${ }^{1)}$, Universitas Pendidikan Indonesia²) \\ Universitas Pendidikan Indonesia3), 4), 5) \\ Email: erwinto@unismuh.ac.id ${ }^{1)}$
}

Submit: 18 Agustus 2021, Revisi: 22 Oktober 2021, Approve: 8 November 2021

\begin{abstract}
Competence plays an important role for teachers. It is also emphasized by the government during the performance of their duties. Teachers' competence is one of the crucial things that they must have in order to teach the students in a class. Based on the results of the questionnaire, it was found that the teachers considered that multiliteracy was something very important as part of the industrial revolution 4.0 era. Multiliteracy is one thing that is competitive in the era of the industrial revolution 4.0 as well as one of the difficult competencies in the 21 st century. Multiliteracy is also a competency that must be possessed by students first by a teacher. In Indonesia itself, every student and teacher is very valuable to have multiliteracy skills. The most widely encountered and mastered literacy by teachers is reading/writing literacy. In teaching multiliteracy, teachers face many obstacles, the obstacles they encounter are integrating basic competencies and determining the right model.Thus, every teacher has to learn how to improve their ability and competence. As the front line in the field of education, teachers need to be prepared to acquire qualified competence in teaching skill. One of the ways to ensure teachers' eligible competence is training. Teacher training is an important key in improving teachers' competence. The purpose of this study is to analyze the effect of teachers' training on competence development. This study used a descriptive quantitative design. The object of this research was 261 teachers in Indonesia. The purpose of this study was to analyze the effect of teacher competence.
\end{abstract}

Keywords: Competence, teacher, literacy, multiliteracy, 21st century learning

Pengutipan: Muh Erwinto Imran, dkk. (2021). Kompetensi Guru dalam Mengajarkan Multiliterasi di Sekolah Dasar. JMIE: Journal of Madrasah Ibtidaiyah Education, 5(2), 2021, 245 249-263. jmie.v5i2.388.

Permalink/DOI: http:/ /dx.doi.org/10.32934/jmie.v5i2.388 


\section{LATAR BELAKANG}

Kebijakan pendidikan di berbagai negara menekankan pentingnya pendidikan sebagai sarana untuk meningkatkan kemampuan dan keterampilan setiap manusia (Dal et al. 2016; Haara et al. 2016). Secara bersamaan, sistem pendidikan didasarkan pada pembagian mata pelajaran dan mata pelajaran sekolah yang berbeda dalam mengembangkan metode dan isi pengajaran. Dalam sistem pendidikan dengan pembagian mata pelajaran yang terstruktur, tema lintas kurikuler, termasuk multiliterasi, harus diintegrasikan ke dalam setiap mata pelajaran (Elo dan Kurtén 2020). Misalnya, musik (Hietanen 2016), matematika (Palmér dan Johansson 2018) dan kerajinan (Elo 2016; Rönkkö dan Lepistö 2016) diintegrasikan ke dalam setiap mata pelajaran. Sebagai sebuah fenomena, multiliterasi belum diselidiki secara optimal terutama di tingkat sekolah dasar dan menengah (Hietanen dan Järvi 2016; Moberg 2014).Di era revolusi industry 4.0, perkembangan dan kemajuan sains dan teknologi yang berkembang begitu pesat terutama perkembangan teknologi dan informasi. Hal ini memberika sinyal kepada kita bahwa dunia pendidikan di Indonesia ditantang untuk dapat menghasilkan lulusan-lulusan yang dapat bersaing di era dengan perkembangan dan kemajuan berbagai bidang yang begitu pesat (Fengliang and Liang 2019). Berangkat dari hal tersebut, maka setiap tenaga pendidik yang ada di Indonesia harus dapat berdaptasi dengan perkembangan zaman yang cepat.

Selain itu, peningkatan tanggung jawab bagi seluruh penduduk dunia saat ini termaksud guru, jelas bahwa semua guru kelas harus memahami dan menguasai berbagai literasi. Setiap guru harus mengajar dan memahamkan literasi secara profesional kepada setiap peserta didik yang mereka temui atau mereka ajar (Sharp, Raymond, and Piper 2020). Para guru juga harus memahami bagaimana cara menerapkan literasi tidak hanya di dalam kelas secara khusus tetapi juga di sekolah secara umum (Tang et al. 2016). Oleh karena itu, mereka harus dapat mempersiapkan diri dalam menagajarkan lieterasi atupun mempelajari literasi.

Sebagai pendidik, para tenaga kependidikan harus memegang keyakinan kuat bahwa mengajar dan mempersiapkan diri mereka adalah hal yang penting (Risko and Reid 2019). Hal tersebut dikarenakan mereka harus meyiapkan segala sesuatu sebelum mereka mengajar termaksud menyiapkan kemampuan literati mereka baik dalam kehidupan keseharian mereka maupun dalam kehidupan mengajar mereka. Pengetahuan mereka tentang literasi akan menjadi tolak ukur dalam profesionalisme meraka dalam mengajar (Francois 2014; Overholt and Szabocsik 2013; Steeg and Lambson 2015). Profesionalisme para guru dalam mengajar juga akan menjadi sebuah indikator bahwa mereka adalah tenaka kependidikan yang mempu menghasilkan generasi yang lebih baik.

Sejak awal sejarah yang tercatat, konsep literasi berarti memiliki makna yaitu keterampilan untuk menafsirkan coretan-coretan pada selembar kertas sebagai huruf yang ketika disatukan, membentuk kata-kata yang pada gilirannya akan menyampaikan makna tersendiri (Carroll et al. 2019). Mengajar para peserta didik untuk menyatukan kata-kata untuk memahami yang pada 
gilirannya, mereka mengekspresikan gagasan yang lebih kompleks menjadi tujuan pendidikan saat berevolusi selama berabad-abad. Ada banyak literasi yang seharusnya dipelajari, dipahami, dimengerti, dan dikuasai tidak hanya oleh tenaga kependidikan dan peserta didik tetapi juga setiap manusia yang berpijak pada bumi saat ini (Caverly et al. 2019). Literasi yang dimaksud antara lain literasi membaca, literasi menulis, literasi sains, literasi teknologi, literasi komunikasi, literasi budaya, literasi keuangan, literasi matematik, literasi digital dan lain-lain (Maher et al. 2019).

Hari ini, informasi tentang dunia di sekitar kita datang kepada kita tidak hanya dengan kata-kata di selembar kertas tetapi juga melalui gambar yang kuat dan suara dari multimedia lainnya. Dari radio jam yang membangunkan kita di pagi hari sampai kita tertidur menonton acara larut malam, kita dihadapkan pada ratusan bahkan ribuan gambar dan gagasan dari tidak hanya televisi tetapi juga situs Web, film, radio talk, majalah sampul, email, permainan video, musik, pesan ponsel, papan iklan, dan banyak lagi (Hasselquist and Kitchel 2019). Hal-hal tersebut memperlihatkan kepada kita betapa pentingnya memiliki kemampuan literasi.

Dalam dunia pendidikan dasar, setiap tenaga pendidik dalam hal ini guru haruslah memiliki kemampuan literasi sebagai bekal mereka dalam melaksanakan proses belajar mengajar. Setengah abad yang lalu, kompetensi guru telah dianggap sebagai hal yang sangat penting untuk membantu setiap peserta didik dalam belajar (van de Grift et al. 2019). Dalam proses pembelajaran tidak hanya dicapai dengan keberanian, tetapi faktor utama adalah kompetensi yang ada dalam kepribadian guru (Wahyuddin 2017). Seorang tenaga pendidik yang memiliki kompetensi yang baik dianggap sebagai salah satu alasan utama kenaikan atau peningkatan prestasi peserta didik (Rink 2013). Semakin tinggi kompetensi maka kesempatan peserta didik dalam meningkatkan kemampuan mereka juga semakin tinggi (Santagata and Sandholtz 2019).

Kompetensi seoarang tenaga pendidik pada intinya adalah melaksanakan tugas mengajar di sekolah. Kompetensi seorang tenaga pendidik adalah kemampuan seorang guru dalam mengemban tanggung jawabnya dalam melaksanakan tugasnya dengan tepat (Wahyuddin 2016). Tenaga pendidik membutuhkan pengetahuan dan pelatihan pedagogis untuk mengembangkan diri mereka sebagai seorang pendidik yang mahir percaya diri akan kemampuan dan kepercayaan mereka sendiri pada siswa potensial (Mohamadi Zenouzagh 2019). Untuk menjadikan peserta didik berkualitas tinggi, guru harus menguasai empat kompetensi. Semua kompetensi harus mampu meningkatkan kualitas guru bersifat pedagogis, profesional, sosial, dan kepribadian. Selain empat kompetensi tersebut, seorang pendidik juga harus memiliki kemampuan literasi (Fisher and Frey 2020).

Di Indonesia sendiri, setiap tenaga pendidik telah diharuskan untuk memiliki kemampuan literasi. Selain itu, sekolah di Indonesia termaksud sekolah dasar telah diterapkan gerakan literasi sekolah. Hal ini menunjukkan kepada kita betapa pentingnya literasi di dalam dunia pendidikan terutama pada sekolah dasar. Oleh karena itu, para guru di Indonesia berupaya keras untuk 
mempelajari, memahami, dan menguasai kemampuan literasi. Dalam penelitian ini, peneliti berupaya mengungkap perspektif para guru sekolah dasar yang di Indonesia tentang multiliterasi serta kesulitan mereka dalam mengajarkan multiliterasi.

\section{METODE PENELITIAN}

Desain penelitian yang digunakan dalam penelitian ini adalah qualitative design. Desain penelitian kualitatif dimulai dari pandangan-padangan teoritis dengan tujuan untuk melakukan penyelidiakan terhadap berbagai permasalahan yang berkaitan dangan iduvidu atau kelompok yang berkaitan dengan permasalahan sosial (Creswell 2015). Desain penelitian ini difokuskan terhadap phenomena yang terjadi pada pelaksanaan pembelajran selama ini. Jenis penelitan yang digunakan dalam penelitian adalah survey. Penelitian ini melibatkan guru sekolah dasar dari beberapa provinsi di Indonesia. Sebanyak 261 guru yang terdiri dari 196 guru perempuan dan 65 guru laki-laki dari 33 provinsi dilibatkan sebagai populasi dalam penelitian ini. Guru-guru tersebut adalah guru kelas dan guru mata pelajaran.

Tujuan dari penelitian ini adalah untuk mengungkap perspektif para guru sekolah dasar yang di Indonesia tentang literasi. Untuk mengetahui hal tersebut, peneliti berupaya untuk mengumpulkan data yang pada gilirannya akan dianalisis sehingga peneliti dapat mengetahui apakah materi tersebut memang sulit bagi peserta didik ataukah sebaliknya. Adapun teknik yang peneliti gunakan dalam mengumpulkan data adalah kuesioner.

Dalam penelitian ini, kuesioner disebarkan oleh peneliti melalui media sosial seperti WhatsApp, Facebook, dan lainnya. Hal ini peneliti lakukan sebab pandemi Covid-19 yang memaksa peneliti untuk menyebar kuesioner menggunakan Google Form melalui media sosial. Data yang didapatkan selanjutnya dianalisis oleh peneliti untuk menemukan jawaban tentang apakah materi pecahan sulit dipahami oleh peserta didik atau sebaliknya.

\section{HASIL PENELITIAN}

Berdasarkan dari manfaat pembelajaran multiliterasi, maka penting bagi setiap tenaga pendidik untuk memahaminya dan mampu mengajarkannya kepada setiap peserta didik. Sebagaimana yang diulas sebelumnya bahwa literasi merupakan hal yang sangat penting bagi setiap tenaga pendidik tidak hanya embel mereka mengajar tetapi juga dalam kehidupan seharihari mereka. Setelah peneliti memberikan kuesioner kepada para guru sekolah dasar berupa mengetahui perpektif mereka tentang multiliterasi, peneliti kemudian memeriksa dan menganalisa hasil dari kuesioner yang peneliti sebarkan. Hasi dari kuesioner tersebut selanjutnya dianalisis oleh peneliti untuk mengetahui perpektif mereka tentang multiliterasi. Adapun, hasil kuesioner dari para guru sekolah yang diberikan tentang pemahaman mereka tentang literasi. Berikut peneliti paparkan pengetahuan tenaga pendidik tentang literasi. 


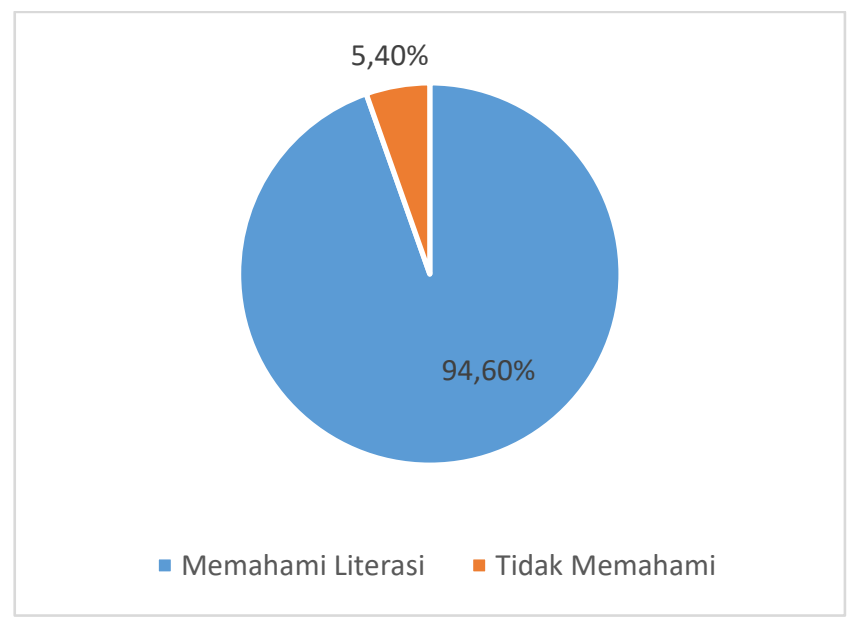

Figure 1 Pengetahuan guru tentang literasi

Dari diagram di atas, kita dapat menemukan bahwa sebanyak 247 guru yang mengisi kuesioner mengatakan bahwa mereka memahami tentang literasi. Sementara itu, sebanyak 14 guru yang mengatakan bahwa tidak memahami tentang literasi. Hal ini menunjukkan kepada kita bahwa guru-guru yang ada di Indonesia kini telah mulai sadar bahwa penting untuk memahami multiliterasi. Pemahaman guru tentang literasi akan memberikan dampak yang besar kepada perkembangan dan kemajuan embelajar yang ada di Indonesia. Dengan semakin banyaknya tenaga pendidik yang memiliki pemahaman tentang literasi, maka diharapkan dapat membantu peserta didik dalam memahami literasi dan mamajukan embelajar Indonesia.

Sebagaimana yang telah dijelaskan di atas bahwa tenaga pendidik yang ada di Indonesia telah memiliki pemahaman tentang literasi. Hal tersebut dapat kita lihat pada hasil kuesioner yang dibagikan oleh peneliti. Para tenaga pendidik dapat memahami memahami multiliterasi dengan menggunakan berbagai cara. Cara-cara tersebut dapat mereka lakukan dengan membaca buku, surat kabar atau yang lainnya. Berikut peneliti paparkan cara para tenaga pendidik dalam hal ini guru dalam memahami literasi.

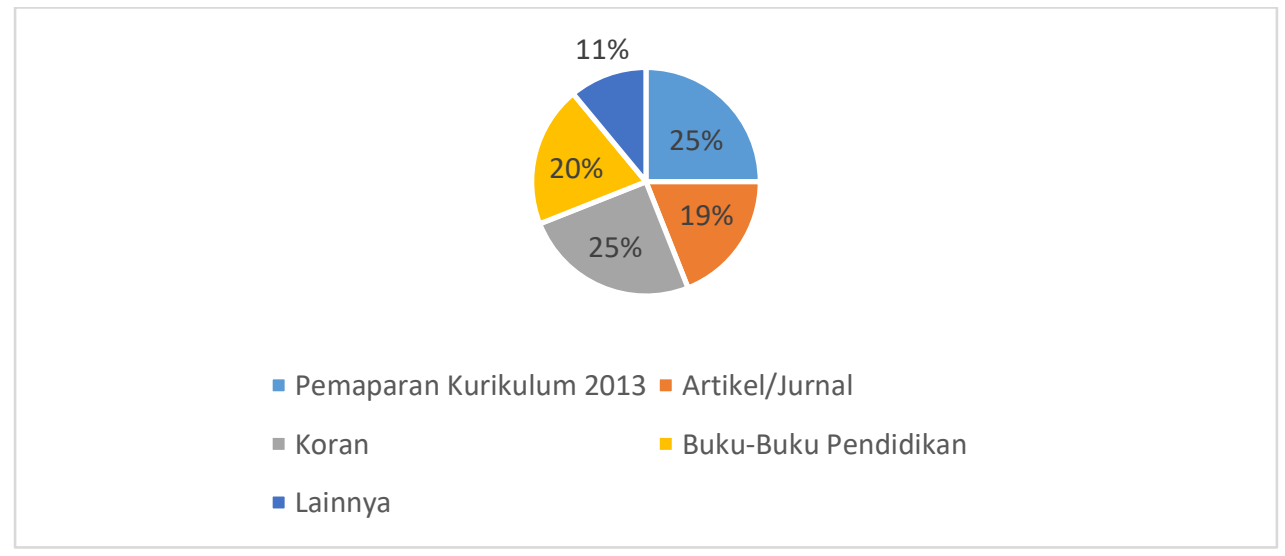

Figure 2 Sumber pengetahuan guru 
Berdasarkan diagram di atas, dapat kita temui bahwa para tenaga pendidik banyak memahami multiliterasi dari pemaparan kurikulum 2013 dan membaca koran atau majalah. Hal ini dapat kita lihat dari diagram diatas bahwa sebanyak 65 tenaga pendidik yang memahami multiliterasi dari pemaparan kurikulum 2013. Tenaga pendidik yang mendapatkan pengetahuan atau pemahaman multiliterasi dari membaca koran adalah sebanyak 65 tenaga pendidik. Sedangkan tenaga pendidik yang mendapatkan pemahaman tentang multiliterasi melalui membaca buku-buku embelajar sebanyak 52 orang. Tidak berbeda jauh dari membaca buku embelajar, para tenaga pendidik juga banyak mendapatkan pemahaman multiliterasi dari membaca artikel atau jurnal, yaitu 50 tenaga pendidik. Sementara itu, tenaga pendidik yang mendapatkan pemahaman multiliterasi dari sumber lainnya sebanyak 29 orang.

Dari pemaparan di atas, dapat kita ketahui bahwa para tenaga pendidik begitu antusias dalam mempelajari dan memahami multiliterasi. Memahami multiliterasi pada dasarnya dapat dilakukan dengan membaca berbagai sumber atau mendengarkan pemaparan dari para ahli. Di dunia ini, khususnya dalam dunia embelajar, ada banyak literasi yang semestinya tiap orang pahami termaksud tenaga pendidik dan para peserta didk. Berikut peneliti paparkan literasi yang diketahui dan dipahami oleh para tenaga pendidik berdasarkan hasil kuesioner yang peneliti bagikan.

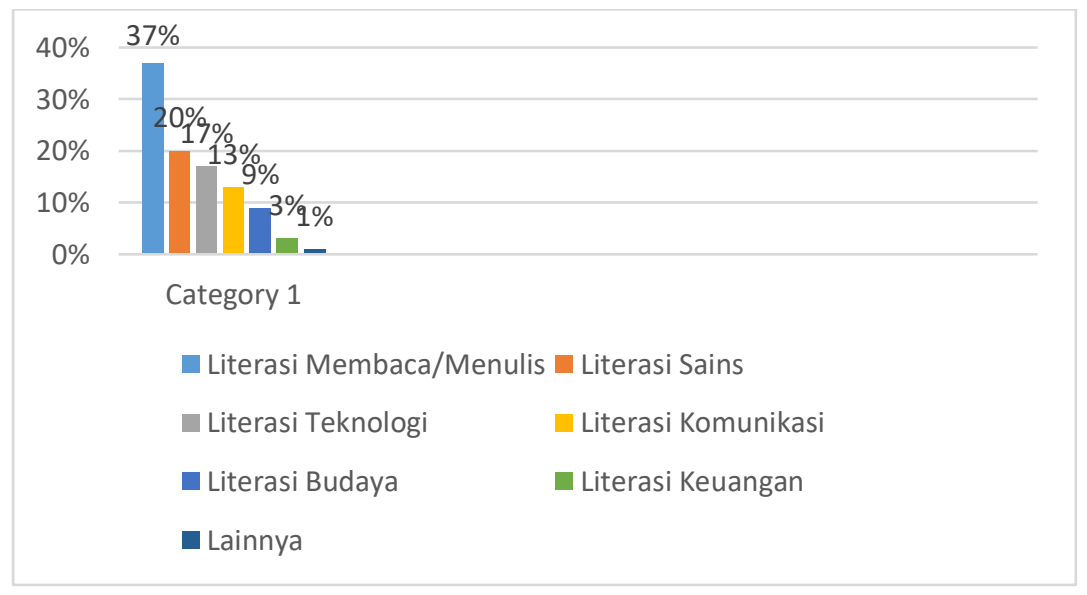

Figure 3 Literasi yang dipahami guru

Berdasarkan diagram di atas, kita dapat melihat bahwa kebanyakan tenaga pendidik memahami literasi membaca/menulis. Hal tersebut dapat kita lihat pada diagram di atas. Terlihat bahwa tenaga pendidik yang memahami literasi membaca/menulis adalah sebanyak 97 dari 261 tenaga pendidik. Pada pemahaman literasi sains, tenaga pendidik yang memahaminya adalah sebanyak 52 orang. Sedangkan tenaga pendidik yang memahami literasi teknologi adalah sebanyak 44 tenaga pendidik. Tidak jauh berbeda dengan literasi sains, literasi komunikasi dipahami oleh sebanyak 34 tenaga pendidik. Sementara itu, untuk literasi budaya, tenaga 
pendidik yang memahaminya hanya sebanyak 23 orang. Untuk literasi keuangan, hanya dipahami oleh 9 orang dan literasi lainnya sebanyak 2 orang saja.

Dari pemaparan di atas, dapat kita ketahui bahwa para tenaga pendidik telah mempelajari dan memahami banyak literasi. Pemahaman tenaga pendidik tentang multiliterasi pada gilirannya akan diajarkan kepada para peserta didik. Melihat begitu pentingnya memiliki pemahaman akan literasi, maka sangat penting bagi para tenaga pendidik untuk mengajarkan literasi kepada para peserta didik. Berikut peneliti paparkan literasi yang menurut tenaga pendidik penting untuk dijarkan kepada para peserta didik berdasarkan kuesioner yang peneliti bagikan.



Figure 4 Literasi yang penting untuk diajarkan

Berdasarkan diagram di atas, kita dapat melihat bahwa kebanyakan tenaga pendidik menaganggap bahwa literasi membaca/menulis paling penting untuk diajarkan, yaitu 91 dari 261 tenaga pendidik. Pada pemahaman literasi sains, tenaga pendidik yang menganggapnya penting untuk diajarkan adalah sebanyak 39 orang. Sedangkan tenaga pendidik yang memilih literasi teknologi untuk diajarkan adalah sebanyak 33 tenaga pendidik. Untuk literasi komunikasi, tenaga pendidik yang menganggap penting untuk diajarkan oleh sebanyak 39 tenaga pendidik. Sementara itu, untuk literasi budaya, tenaga pendidik yang menganggapnya penting untuk diajarkan sebanyak 31 orang. Untuk literasi keuangan, hanya 23 orang dan literasi lainnya sebanyak 5 orang saja.

Dari pemaparan di atas, kita ketahui bahwa para tenaga pendidik telah mengajarkan berbagai literasi kepada para peserta didik. Hal ini memang perlu untuk dilakukan mengingat literasi merupakan salah satu hal yang sangat dituntut di era revolusi industry 4.0. Namun, bukan berarti bahwa para tenaga pendidik tidak mengalami kesulitan dalam mengajarkan literasi kepada para peserta didik. Dari 261 partisipan dalam penelitian ini, 94,3\% mengatakan bahwa mereka menemukan kendala dalam mengajarkan literasi sementara sisanya mengatakan bahwa mereka 
tidak menemukan kendala yang berarti. Kendala-kendala yang mereka temui dalam mengajarkan litersi diataranya adalah membuat persiapan mengajar dalam hal ini rencana pelaksanaan pembelajaran (RPP), menentukan model yang tepat, dan lain-lain. Untuk lebih jelasnya, peneliti menggambarkannya dalam bentuk diagram di bawah ini.

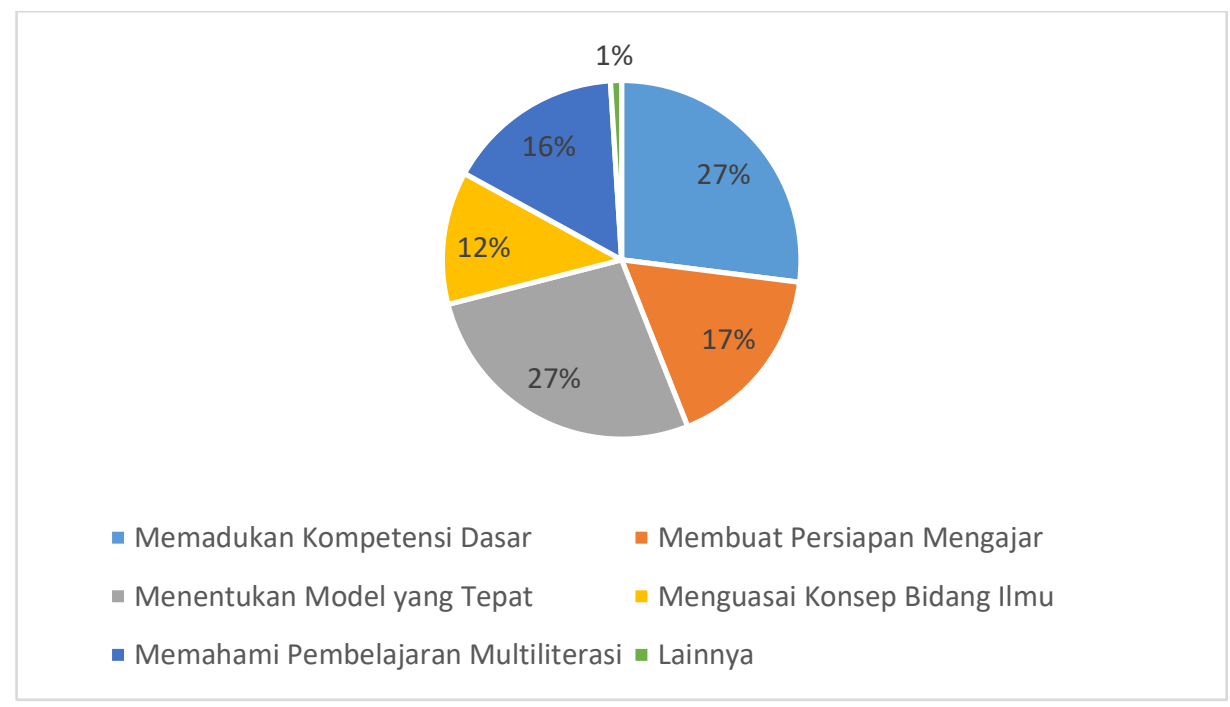

Figure 5 Kesulitan guru mengajarkan literasi

Dari pemaparan di atas, kita dapat ketahui bahwa para tenaga pendidik banyak mengalami kesulitan dalam mengajarkan multiliterasi. Berdasarkan diagram di atas, dapat kita lihat bahwa tenaga pendidik yang mengalami kesulitan dalam mengajarkan multiliterasi embel memadukan kompetensi dasar (KD) yang sesuai adalah sebanyak 70 dari 261 tenaga pendidik yang menjadi partisipan dalam penelitian ini. Dalam membuat persiapan mengajar (RPP), tenaga pendidik yang mengalami kesulitan adalah sebanyak 44 orang. Pada saat menentukan model yang tepat, tenaga pendidik yang mengalami kesulitan adalah sebanyak 70 tenaga pendidik. Sedangkan menguasai konsep bidang ilmu yang dipelajari siswa, tenaga pendidik yang mengalami kesulitan adalah sebanyak 32 orang. Sementara itu, tenaga pendidik yang mangalami kesulitan embel memahami pembelajaran multiliterasi adalah sebanyak 42 partisipan dan yang lainnya sebanyak 3 orang.

Berdasarkan pemapamaran di atas, maka penting bagi para tenaga pendidik untuk mempersiapkan segala sesuatunya dalam mengajarkan multiliterasi kepada peserta didik. Hal ini juga disampaikan oleh para tenaga pendidik yang menjadi partisipan di dalam penelitian ini. Dari hasil kuesioner yang peneliti bagikan, sebanyak 196 dari 261 tenaga pendidik 75,1\% yang mengatakan bahwa persiapan pembelajaran sebelum mengajarkan multiliterasi sangat penting sementara 65 tenaga pendidik yang mengatakan penting. Sehingganya, para tenaga pendidik membutuhkan penunjang yang dapat membantu mereka dalam melaksanakan proses pembelajaran. Penujang-penunjang yang dimaksud meliputi penguasaan materi, model 
pembelajaran, dan lainnya. Untuk lebih jelasnya, peneliti menggambarkannya dalam bentuk diagram di bawah ini.

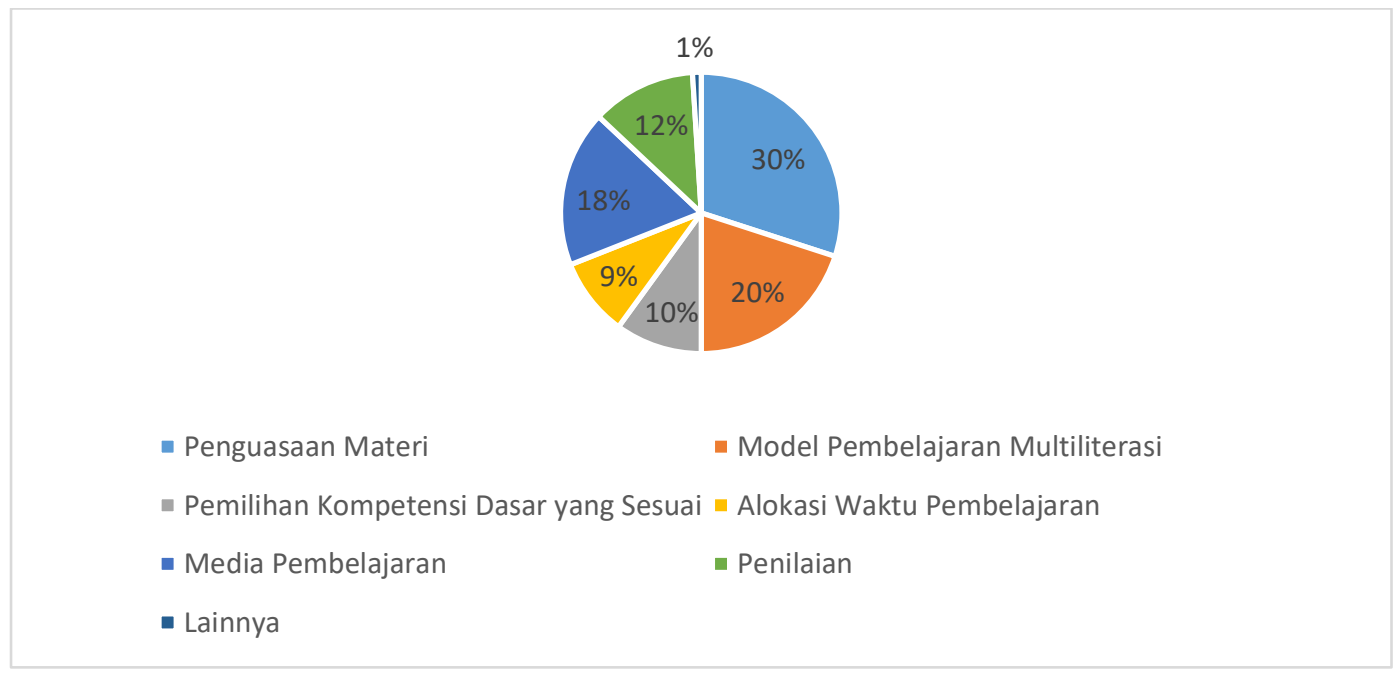

Figure 6 Penunjang pembelajaran multiliterasi

Berdasarkan diagram di atas, kita dapat melihat bahwa kebanyakan tenaga pendidik menaganggap bahwa penguasaan materi merupakan penunjang yang paling baik sebelum melaksanakan pembalajran, yairu 78 dari 261 tenaga pendidik. Pada model pembelajaran multiliterasi, tenaga pendidik yang menganggapnya sebagai penunjang penting sebelum proses pembelajaran adalah sebanyak 52 orang. Sedangkan tenaga pendidik yang menganggap bahwa pemilihan kompetensi dasar yang sesuai adalah penunjang persiapan sebelum megajar adalah penting sebanyak 26 tenaga pendidik. Untuk alokasi waktu pembelajaran, tenaga pendidik yang menganggap sebagai penunjang penting sebelum mengajar adalah sebanyak 24 tenaga pendidik. Sementara itu, untuk media pembelajaran, tenaga pendidik yang menganggapnya penting sebanyak 47 orang. Untuk penilaian, sebanyak 31 orang dan lainnya sebanyak 3 orang saja.

Selain mempersiapkan penunjang embelajaran, tenaga pendidik juga meminta para peserta didik untuk menggali informasi tambahan yang dapat meningkatkan kemampuan multiliterasi peserta didik. Dari hasil kuesioner yang peneliti bagikan, peneliti menemukan bahwa sebanyak 84 dari 261 tenaga pendidik yang menginstruksikan peserta didik untuk menggali informasi tambahan mengenai literasi dari buku. Tenaga pendidik yang menginstruksikan peserta didik untuk menggali informasi tambahan mengenai literasi dari artikel adalah sebanyak 18 tenaga pendidik. Sebanyak 23 tenaga pendidik yang menginstruksikan peserta didik untuk menggali informasi tambahan mengenai literasi dari majalah. Tenaga pendidik yang menginstruksikan peserta didik untuk menggali informasi tambahan mengenai literasi dari koran adalah sebanyak 21 orang. Sementara itu, sebanyak 60 tenaga pendidik yang menginstruksikan peserta didik untuk menggali informasi tambahan mengenai literasi dari google. Sedangkan tenaga pendidik yang menginstruksikan peserta didik untuk menggali informasi tambahan mengenai 
literasi dari youtube adalah sebanyak 29 tenaga pendidik. Sedangkan yang lainnya adalah sebanyak 26 orang. Untuk lebih jelasnya dapat kita lihat pada diagram di bawah.

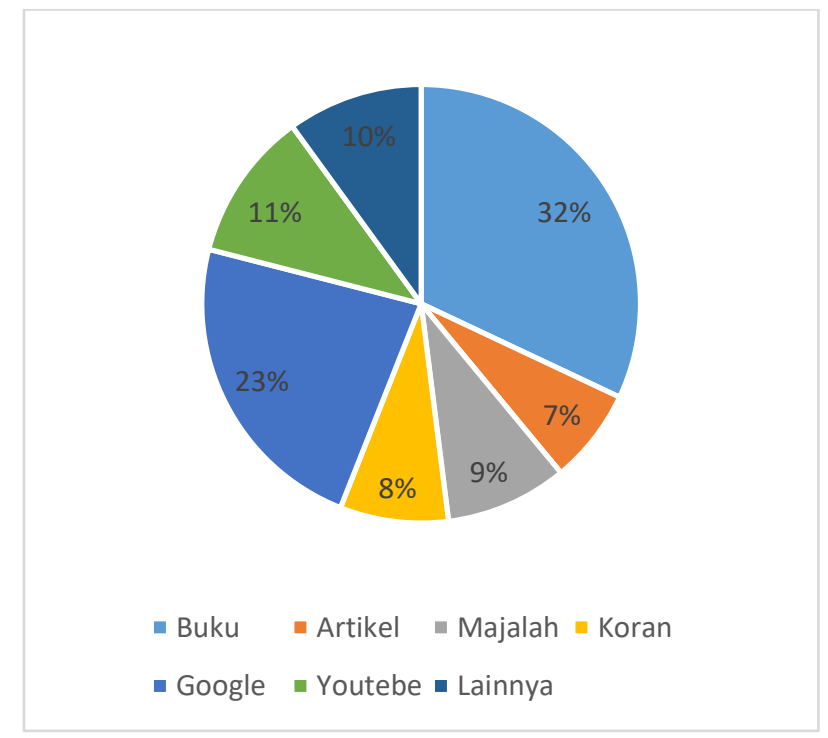

Figure 7 Sumber informasi lain

\section{PEMBAHASAN}

Literasi merupakan salah satu hal yang menjadi keharusan untuk dipelajari dan dikuasai baik oleh para tenaga pendidik maupun oleh para peserta didik. Hal ini dikarenakan literasi menjadi sesuatu yang dituntut di era revolusi industri 4.0 dan juga hal yang menjadi keharusan di abad 21. Para guru dan peserta didik akan diperhitungkan kapabilitasnya apabila memiliki kemampuan literasi. Sebab, di era revolusi industri 4.0 perkembangan teknologi, informasi dan komunikasi sangat pesat (Walker 2015).

Dengan banyaknya literasi yang seyogyanya dipahami dan dikuasai oleh tenaga pendidik dan para peseta didik membuat para tenaga pendidik dan peserta didik harus bekerja keras dalam memahami semua literasi tersebut. Dengan banyaknya literasi yang harus dipahami dan dikuasai oleh setiap tenaga pendidik dan peserta didik, maka tidak salah apabila muncul sebuah gerakan, yaitu gerakan sekolah literasi (Loring 2017).

Apabila kita mencermati pemaparan hasil penelitian di atas, kita dapat melihat bahwa guru-guru yang ada di Indonesia telah banyak memahami masalah literasi. Hal ini menunjukkan kepada kita bahwa pemahaman dan penguasaan guru tentang literasi adalah hal yang sangat penting. Hal ini juga disampaikan oleh (Shearer et al. 2018) yang mengatakan bahwa para tenaga pendidik yang mengajar haruslah memahami dan menguasai literasi. Sebab, literasi bisa menjadi hal yang mengantarkan mereka ataupun peserta didik kepada suatu kemajuan peradaban (Cassidy, Grote-Garcia, and Ortlieb 2020). 
Para tenaga pendidik seharusnya senantiasa mendapatkan dorongan dan pemaparan materi tentang literasi. Berdasarkan pemaparan hasil di atas, terlihat bahwa kebanyakan tenaga pendidik Indonesia mendapatkan pemahaman yang tentang literasi dari berbagai pemaparan materi yang mereka ikuti. Terlihat pula bahwa kebanyakan tenaga pendidik yang ada di Indonesia memahami literasi membaca dan menulis. Hal ini juga disampaikan oleh (Hartley 2020) yang mengatakan bahwa literasi membaca dan menulis merupakan literasi yang paling mudah untuk dipahami dan dikuasai oleh tenaga pendidik ataupun peserta didik. Karena tenaga pendidik paling memahami dan menguasai literasi membaca dan menulis, maka mereka menganggapnya sebagai literasi yang paling penting untuk diajarkan. (Alcock, Ngorosho, and Jukes 2018) mengatakan bahwa literasi yang telah dikusai oleh seseorang akan lebih mudah untuk diajarkan kepada orang lain. Selain itu, (Bendiksen, Østern, and Belliveau 2019) juga mengatakan bahwa literasi membaca dan menulis adalah literasi yang paling penting untuk dipahami dan dikuasai oleh setiap orang yang belajar.

Ketika para tenaga pendidik telah memahami literasi, maka mereka harus mengajarkannya kepada para peserta didik. Namun, dalam perjalanannya, para tenaga pendidik mendapatkan kesulitan dalam mengajarkan literasi. berdasarkan pemaparan hasil di atas, dapat kita lihat bahwa tenaga pendidik mengalami kesulitan dalam memadukan kompetensi dasar dan menentukan model yang tepat. Menentukan model yang tepat untuk mengajarkan literasi adalah salah satu hal yang sulit (Manten et al. 2020). Hal ini dikarenakan tidak semua model dapat memberikan kemudahan kepada para tenaga pendidik dalam mengajarkan literasi.

\section{KESIMPULAN}

Berdasarkan pembahasan di atas, maka dapat kita simpulkan bahwa memiliki kemampuan multiliterasi adalah hal yang sangat penting sebagai jawaban atas tutuntan era revolusi industri. Setiap tenaga pendidik menganggap bahwa multiliterasi merupakan sesuatu hal yang sangat penting dimana literasi yang paling banyak mereka pahami dan kuasai adalah literasi membaca/menulis. Setiap tenaga pendidik harus mampu mempelajari, memahami dan mengajarkan literasi kepada para peserta didik. Dalam perjalanannya, para tenaga pendidik mengalami kesulitan dalam mengajarkan multiliterasi kepada para peserta didik. Kesulitankesulitan yang mereka alami itu adalah memadukan kompetensi dasar dan menentukan model yang tepat.

\section{SARAN}

Berdasarkan pemaparan kesimpulan di atas, hal-hal yang peneliti sarankan adalah setiap tenaga pendidik harus dapat memahami dan mengajarkan literasi dengan baik kepada para 
peserta didik. Selain itu, para tenaga pendidik dapat menggunakan model RADEC dalam mengajarkan multiliterasi.

\section{DAFTAR PUSTAKA}

Alcock, Katherine J., Damaris S. Ngorosho, and Matthew C. H. Jukes. 2018. "Reading and Phonological Awareness in Africa." Journal of Learning Disabilities 51(5):463-72.

Aruguete, Mara S., Ho Huynh, Blaine L. Browne, Bethany Jurs, Emilia Flint, and Lynn E. McCutcheon. 2019. "How Serious Is the 'Carelessness' Problem on Mechanical Turk?” International Journal of Social Research Methodology 22(5):441-49.

Bendiksen, Solveig Åsgard, Anna-Lena Østern, and George Belliveau. 2019. “Literacy Events in Writing Play Workshops with Children Aged Three to Five: A Study of Agential Cuts with the Artographic Triple Dimensions as a Lens." International Journal of Education and the Arts 20(3):1-28.

Bills, Matthew A., Eryn Nicole O. Neal, Brittany E. Hayes, A. Katherine, Matthew A. Bills, Eryn Nicole O. Neal, Brittany E. Hayes, Katherine A. Meeker, Matthew A. Bills, Eryn Nicole O. Neal, Brittany E. Hayes, and Katherine A. Meeker. 2019. "Writing between the Lines : Examining Unprompted Handwritten Student Comments on a Campus Climate Survey Writing between the Lines : Examining Unprompted Handwritten Student Comments on a Campus Climate Survey." Journal of School Violence 19(2):205-18.

Blaney, Jennifer M., Linda J. Sax, and Connie Y. Chang. 2019. "Incentivizing Longitudinal Survey Research: The Impact of Mixing Guaranteed and Non-Guaranteed Incentives on Survey Response." Review of Higher Education 43(2):581-601.

Brenner, Philip S. 2019. "Can Phishing Tank Survey Response Rates? Evidence from a Natural Experiment." Field Methods 31(4):295-308.

Carroll, Julia M., Andrew J. Holliman, Francesca Weir, and Alison E. Baroody. 2019. "Literacy Interest, Home Literacy Environment and Emergent Literacy Skills in Preschoolers." Journal of Research in Reading 42(1):150-61.

Cassidy, Jack, Stephanie Grote-Garcia, and Evan Ortlieb. 2020. “What's Hot in 2019: Expanded and Interconnected Notions of Literacy." Literacy Research and Instruction 59(1):39-52.

Caverly, David C., Emily M. Payne, Amarilis M. Castillo, Amber Sarker, Elizabeth Threadgill, and Daniel West. 2019. "Identifying Digital Literacies to Build Academic Literacies." Journal of College Reading and Learning 49(3):170-205.

Creswell, Jhon. 2015. Riset Pendidikan: Perencanaan, Pelaksanaan, Dan Evaluasi Riset Kualitatif Dan Kuantitatif. 5th ed. Yogyakarta: Pustaka Pelajar. 
Dal, Michael, Janne Elo, Eva Leffler, Gudrun Svedberg, and Mats Westerberg. 2016.

"Research on Pedagogical Entrepreneurship-a Literature Review Based on Studies from Finland, Iceland and Sweden.” Education Inquiry 7(2):159-82. doi: 10.3402/edui.v7.30036.

Elo, Janne. 2016. "Enterprise Education through Sloyd." Techne Series: Research in Sloyd Education and Craft Science A 23(2):34-49.

Elo, Janne, and Berit Kurtén. 2020. "Exploring Points of Contact Between Enterprise Education and Open-Ended Investigations in Science Education." Education Inquiry 11(1):18-35. doi: 10.1080/20004508.2019.1633903.

Fengliang, Li, and Wang Liang. 2019. "Over-Education and Income of the Distance Learner." Asia-Pacific Education Researcher 28(5):421-28.

Fisher, Douglas, and Nancy Frey. 2020. "Make Deliberate Practice Part of Your Classroom Routine." Journal of Adolescent \& Adult Literacy 63(5):593-96.

Francois, Chantal. 2014. "Getting at the Core of Literacy Improvement: A Case Study of an Urban Secondary School." Education and Urban Society 46(5):580-605.

Ganci, S. 2018. “A New (?) Physiological Effect in a Demonstration Experiment in Geometrical Optics." Physics Education 53(2).

van de Grift, Wim J. C. M., Thoni A. M. Houtveen, Henk T. G. van den Hurk, and Oscar Terpstra. 2019. "Measuring Teaching Skills in Elementary Education Using the Rasch Model." School Effectiveness and School Improvement 30(4):455-86.

Haara, Frode Olav, Eirik S. Jenssen, Ingrid Fossøy, and Inger Karin Røe Ødegård. 2016. “The Ambiguity of Pedagogical Entrepreneurship-the State of the Art and Its Challenges." Education Inquiry 7(2):183-210. doi: 10.3402/edui.v7.29912.

Hartley, Jenny. 2020. “Twenty Years behind Bars : Reading Aloud in Prison Reading Groups Twenty Years behind Bars: Reading Aloud in Prison Reading." Changing English 27(1):100-108.

Hasselquist, Laura, and Tracy Kitchel. 2019. "South Dakota State University." Career and Technical Education Research 44(2):32-55.

Hietanen, Lenita, and Taina Järvi. 2016. "Journal of Enterprising Communities : People and Places in the Global Economy Article Information :" Journal of Enterprising Communities 10(4):29. doi: 10.1108/JEC-03-2013-0006.

Jackson, Sherri L. 2010. Research Methods: A Modular Approach. 2nd ed. Belmont, CA: Wadsworth. Loring, Ariel. 2017. "Literacy in Citizenship Preparatory Classes.” Journal of Language, Identity and Education 16(3):172-88. 
Maher, Anthony, David Morley, Julie Fimusanmi, and Paul Ogilvie. 2019. "The Impact of a Special School Placement on Self-Perceptions of Confidence and Competence among Prospective PE Teachers.” European Physical Education Review 25(2):474-90.

Manten, Aileen, Mia le Roux, Salomé Geertsema, and Marien Graham. 2020. "An Investigation into the Early Literacy Skills of English Second Language Learners in South Africa." Australasian Journal of Early Childhood 45(2):142-54.

Mohamadi Zenouzagh, Zohre. 2019. "The Effect of Online Summative and Formative Teacher Assessment on Teacher Competences.” Asia Pacific Education Review 20(3):343-59.

Ngozwana, Nomazulu. 2018. "Ethical Dilemmas in Qualitative Research Methodology: Researcher's Reflections." International Journal of Educational Methodology 27(1):33-59.

Overholt, Rebecca, and Sandra Szabocsik. 2013. "Leadership Content Knowledge for Literacy: Connecting Literacy Teachers and Their Principals." The Clearing House: A Journal of Educational Strategies, Issues and Ideas 86(2):53-58.

Prabowo, Aan, and Heriyanto. 2013. "Analisis Pemanfaatan Buku Elektronik (E-Book) Oleh Pemustaka Di Perpustakaan SMA Negeri 1 Semarang." Jurnal Ilmu Perpustakaan 2(2):1-9.

Rink, Judith E. 2013. “Teacher Effectiveness in Physical Education.” Research Quarterly for Exercise and Sport 84(4):407-18.

Risko, Victoria J., and Louann Reid. 2019. "What Really Matters for Literacy Teacher Preparation?” Reading Teacher 72(4):423-29.

Santagata, Rossella, and Judith Haymore Sandholtz. 2019. "Preservice Teachers' Mathematics Teaching Competence: Comparing Performance on Two Measures." Journal of Teacher Education 70(5):472-84.

Sharp, Laurie A., Roberta D. Raymond, and Rebekah Piper. 2020. "Exploring the Literacy Leadership Practices of Literacy Teacher Educators." Teacher Educators' Journal 13(1):1231.

Shearer, Cara, Hannah R. Goss, Lowri C. Edwards, Richard J. Keegan, Zoe R. Knowles, Lynne M. Boddy, Elizabeth J. Durden-Myers, and Lawrence Foweather. 2018. "How Is Physical Literacy Defined? A Contemporary Update." Journal of Teaching in Physical Education 37(3):237-45.

Somantri, Gumilar Rusliwa. 2005. "Memahami Metode Kualitatif.” Makara, Sosial Humaniora $9(2): 57-65$.

Standish, Trey, and Paul D. Umbach. 2018. "Should We Be Concerned About Nonresponse Bias in College Student Surveys? Evidence of Bias from a Validation Study." Research in Higher Education 60(3):338-57.

Steeg, Susanna M., and Dawn Lambson. 2015. "Collaborative Professional Development: One 
School's Story.” Reading Teacher 68(6):473-78.

Tang, Sylvia Y. F., May M. H. Cheng, Angel K. Y. Wong, Sylvia Y. F. Tang, May M. H. Cheng, and Angel K. Y. Wong The. 2016. "The Preparation of Pre-Service Student Teachers' Competence to Work in Schools." Journal of Education for Teaching: International Research and Pedagogy 42(2):149-62.

Wahyuddin, Wawan. 2016. “The Relationship between of Teacher Competence, Emotional Intelligence and Teacher Performance Madrasah Tsanawiyah at District of Serang Banten." Higher Education Studies 6(1):128-35.

Wahyuddin, Wawan. 2017. "Headmaster Leadership and Teacher Competence in Increasing Student Achievement in School." International Education Studies 10(3):215-26.

Walker, Anne B. 2015. "Giving Literacy, Learning Literacy: Service-Learning and School Book Drives." Reading Teacher 69(3):299-306.

Yona, S. 2006. "Penyusunan Studi Kasus." Jurnal Keperawatan Indonesia 10(2):76-80. 